\title{
Geomorphological Mapping Using Remote Sensing and GIS A Tool for Land Use Planning Around Shivpuri City, M.P., India
}

\author{
Ajay Singh Tomar ${ }^{1}$, U.C.Singh ${ }^{2}$ \\ ${ }^{1,2}$ (S.O.S Earth Science, Jiwaji University Gwalior, M.P., India)
}

\begin{abstract}
Landforms on the earth surface are expensive to map or monitor. Remote Sensing observations from space platforms provide a synoptic view of terrain on images. Satellite multispectral data have an advantage in that the image data in various bands can be subjected to digital enhancement techniques for highlighting contrasts in objects for improving image interpretability. Landforms are interpreted on the basis of interpretation element keys namely such as- tone, texture, size, shape, color etc. and extract the specific information from the false color composites LISS-III sensor images. Geomorphological units are classified on the basis differential erosion processes. In the study area, mainly presentational hills of Vindhyan sediments and pediments of granites are predominant landforms. Apart from these above geomorphic units, alluvial plain, pediplain, structural hills and residual hills are mapped using IRS-ID LISS-III satellite imagery using visual interpretation technique along with field check. Remote Sensing and GIS offers detecting, analyzing and timecost effective way to fulfill these goals.
\end{abstract}

Keywords- Geomorphology mapping, GIS, IRS-1D, LISS-III, Remote Sensing

\section{Introduction}

Now-a-days, Land use planning is important task for local and government authority to provide suitable land for human activities in the study area so it is realized that land use planning need to be developed in an integrated and comprehensive manner based on geomorphic study. In this study, Remote Sensing and GIS, tools and techniques are used to identify landform, geomorphic units and area mapping because geomorphology is the base of land use planning.

\section{Study Area}

The area under study lies between $25^{\circ} 20^{\prime}-25^{\circ} 30^{\prime}$ degrees latitude and $77^{\circ} 35^{\prime}-77^{\circ} 45^{\prime}$ degrees longitude and falls in SOI toposheet number 54G/11 covering total area of approximately- $309 \mathrm{sq} . \mathrm{km}$ and height from the mean sea level is $521.5 \mathrm{~m}$. It forms a part of Shivpuri district which is bounded on the north and south by Gwalior and Guna districts of M.P. respectively, on the east by Jhansi district (U.P.), and on the west by Kota district of Rajasthan Figure 2.1.

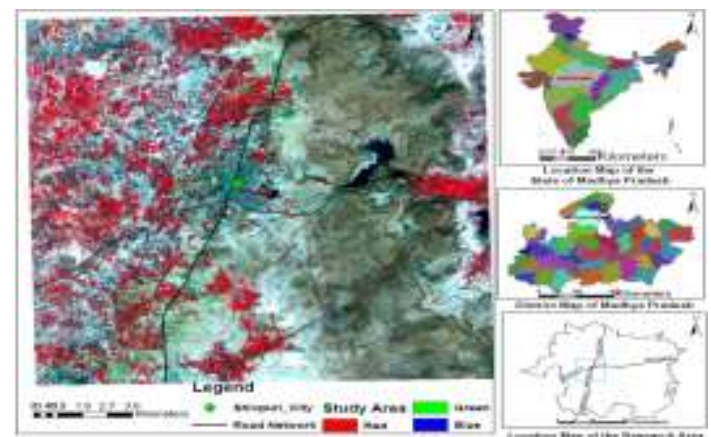

Figure I: location map of the study area with irs-1d liss-III $\left(24^{\text {th }}\right.$ january, 2006) image

\section{Data Used And Methodology}

NRSA (National Remote Sensing Agency, Hyderabad) collected the IRS-1D LISS-III data $\left(24^{\text {th }}\right.$ January, 2006) in digital form and topographic map 54G/11 at scale 1:50,000 published by Survey of India (SOI) have been utilized. Digital data registered with SOI toposheet and identified different hydrogeomorphological units, mapping with image interpretation techniques, digital image processing, exiting geology and geomorphology map using Erdas 8.6 and ArcGIS 9.0 and verified with GCPs collection. 


\section{Results And Discussion}

The earth's surface forms are primarily due to hypogene or endogenous processes. Geomorphology is the science and study of landforms on the earth. Both the disciplines are exhaustively covered in literature [1]. Today, all land use planning processes in most of the countries are based on geomorphological units [2]. The shivpuri city is the smallest area, for development of land use; all planning should be based on the character of the geomorphological environment of study area. Geomorphology unit are dynamic in nature as they are affected by various human activities, including the expansion of cultivated and irrigated lands, industrialization, urbanization and others because it need to monitoring, mapping for land use planning [3]. Geomorphic units are classified on the basis of differential erosion processes [4]. Mainly denudational hills of Vindhyan sediments and pediments of granites are predominant landforms.

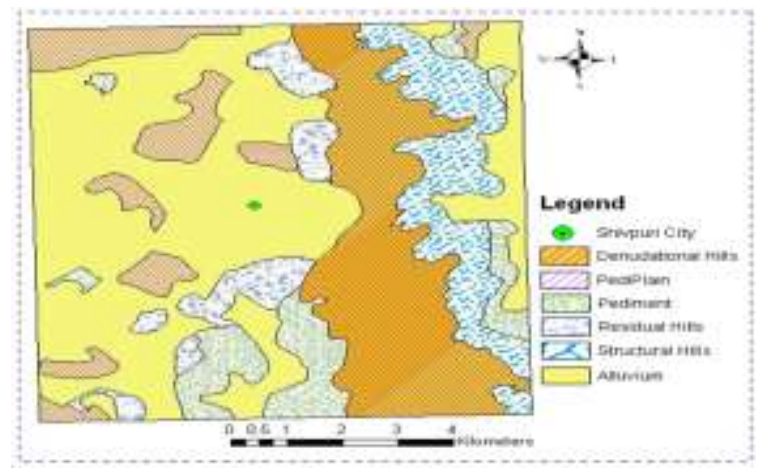

Figure II: geomorphological map of the study area

\begin{tabular}{|l|l|l|l|l|l|l|}
\hline $\begin{array}{l}\text { Geomorphic } \\
\text { Units }\end{array}$ & $\begin{array}{l}\text { Denudatio } \\
\text { nal Hills }\end{array}$ & $\begin{array}{l}\text { Structur } \\
\text { al Hills }\end{array}$ & $\begin{array}{l}\text { Residual } \\
\text { Hills }\end{array}$ & Pediment & Pediplain & $\begin{array}{l}\text { Alluvial } \\
\text { Plain }\end{array}$ \\
\hline $\begin{array}{l}\text { LISS-III Area } \\
\left(\begin{array}{l}\text { (2006) } \\
\text { (sq.-km) }\end{array}\right.\end{array}$ & 66.341 & 37.330 & 18.571 & 27.272 & 27.194 & 132.292 \\
\hline
\end{tabular}

Table 1: geomorphic units

\section{IV.I Denudational Hills}

Denudational hills are the massive hills with resistant rock bodies that are formed due to differential erosional and weathering processes [4]. These hills are composed of Vindhyan sediments which are fractured, jointed having no soil cover moderate to steep slope. On the satellite image, these landforms were identified by light or dark brownish with mix green color due to thick forest cover. Denudational hills occupying eastern and western portions of the study area cover about 66 66.341sq.km in geomorphic maps (Fig. 2) and (Table 1).

\section{IV.II Structural Hills}

Structural hills are representing the geologic structures such as- bedding, joint, lineaments etc [5]. in the study area. They are located in the eastern parts of the study area having greenish and reddish tone with rough texture on the satellite image. Approximately, the area under structural hills covers $37.330 \mathrm{sq} . \mathrm{km}$ in geomorphic maps (Fig. 2) and (Table 1).

\section{IV.III Residual Hill}

Residual Hills Are The End Products Of The Process Of Pediplanation, Which Reduces The Original Mountain Masses Into A Series Of Scattered Knolls Standing On The Pediplains [5]. Residual Hills Occur As Small Hills Comprise Of More Resistant Formations Formed Due To Differential Erosion Are Found In The Western And South Western Portions Of The Study Area. In The Imageries, These Features Occur As Dark Greenish Brown Patches With Forest Cover. The Cover An Area 18.571 Sq.Km In Geomorphic Maps (Fig. 2) And (Table 1).

\section{IV Pediment}

In The Study Area, Pediments Are Gently Sloping Areas Or Erosional Surface Of Bed Rock. Pediments May Or May Not Be Covered By A Thin Layer Of Alluvium And Are Mostly Developed At The Foot Of The Hills Occuring Along The Eastern Margin And In The Southern Portion Of The Study Area. These Landforms Are Showing Light Greenish Color And Fine Texture. It Covers An Area Of 27.272 Sq.Km In Geomorphic Maps (Fig. 2) And (Table 1). 


\section{IV.V Pediplain}

Pediplains are formed due to intensive weathering under semi arid climatic conditions, representing final stage of the cyclic erosion [6]. These are identified in the imageries due to grey tone on false color composite. Pediplain have developed in the western and north eastern portions of area under in investigation as a result of continuous erosional process. It covers an area of 27.194 sq.km in geomorphic maps (Fig. 2) and (Table 1).

\section{IV.VI Alluvial Plain}

An alluvial plain is a relatively flat landform and created by the deposition of highlands eroded due to weathering and water flow in study area [7]. The sediment from the hills is transported to the lower plain over a long period of time. It identified on the imageries dark reddish moderate to fine texture due to agriculture activities. Alluvial deposits of the area constitute gravel, sand, silt or clay sized unconsolidated material. It covers an area of $132.292 \mathrm{sq} . \mathrm{km}$ in the central and western portions of geomorphic maps (Fig. 2) and (Table 1).

\section{IV.VII GIS Layer Generation and Analysis}

A GIS is an automated tool for efficient storage, analysis and presentation of geographically referenced data means facilitating the creation and use of information. It aims at storage and retrieval of all types of data at a particular location in space and identifying data needs acquisition of data, management, processing and decision making [8]. In the present study, various thematic geomorphic units namely are pediment, pediplain, alluvial plain, residual hills, structural hills and denudational hills have been generated.

\section{Conclusion}

The approach and results discussed in this paper. Land use planning is continuous process due to natural and human causes. For future land use planning, it is necessary to understand the existing geomorphic units and extents. Remote Sensing and GIS have capability to mapping geomorphic units [9]. It is provides the large view of earth surface features on the satellite and have various tools, technique to explore the geographic features. The geomorphic units mapped from satellite image as denudational hills majorly occupying eastern and western portions, structural hills eastern parts, residual hills western and south western portions, pediment eastern margin and in the southern portion, pediplain western and north eastern, alluvial plain central and western portions of the map. Now, based on mapped geomorphic units local and government authority can make decision to land use planning for human activities.

\section{REFERENCES}

[1]. Blaschke T., Object-based image analysis for remote sensing, ISPRS journal of Photogrammetry and Remote Sensing 65(1), 2010, pp. 2-16.

[2]. Drăguț, L., Blaschke, T., Automated classification of landform elements using object-based image analysis, Geomorphology, 81, 2006, pp. 330-344.

[3]. Jenson, S. K., J. Domingue. J.O., 1988. Extracting Topographic Structure from Digital Elevation Data for Geographic Information System Analysis. Photogrammetric Engineering and Remote Sensing 54, pp. 1593-1600.

[4]. Yokoyama R, Shirasawa M., Pike R.J., Visualizing topography by openness: a new application of image processing to digital elevation models, Photogrammetric Engineering and Remote Sensing, 68, 2002, pp. 257-265.

[5]. Mith M. J., Clark C. D., Methods for the Visualization of Digital Elevation Models for Landform Mapping, Earth Surface Processes and Landforms, Vol. 30, 2005, Pages 885 - 900.

[6]. Krishnamurthy $\mathbf{J}$ and Srinivas G, Role of geological and geomorphological factors in groundwater exploration: a study using IRS LISS data, International Journal of Remote Sensing 16(14), 1995, pp 2595-2618.

[7]. Kalluri, S.; Gilruth, P.; Bergman, R. The potential of remote sensing data for decision makers at the state, local and tribal level: experiences from NASA's Synergy program, Environmental Science Policy 6, 2003, 487-500.

[8]. Jaiswal RK, Krishnamurthy J, Mukhergee S, Regional study for mapping the natural resource prospects \& Problem zones using remote sensing and GIS, Geocarto International 20 (3), 2005, 21-31.

[9]. G. P. Obi Reddy, A. K. Maji, Dleineation and characterization of geomorphological features in a part of lower maharahstra metamorphic plateau using IRS-ID LISS-III Data, Journal of the Indian Society of Remote Sensing, Volume 31, Issue 4, 2003, pp 241-250. 